\title{
PENINGKATAN KEMAMPUAN GURU DALAM MENETAPKAN KRITERIA KETUNTASAN MINIMAL (KKM) MAPEL MATEMATIKA MELALUI RAPAT KERJA KKG SEKOLAH DI SD NEGERI TEGALWANGI 01
}

\author{
Rokhmat \\ SD Negeri Tegalwangi $01 \mathrm{Kab}$. Tegal \\ rokhmat_46@yahoo.co.id
}

\begin{abstract}
ABSTRAK
Permasalahan dalam penelitian tindakan sekolah ini adalah bahwa dari hasil wawancara menunjukkan bahwa guru SD Negeri Tegalwangi 01 dalam menetapkan Kriteria Ketuntasan Minimal tidak berdasarkan analisis dan tidak memperhatikan prinsip serta langkah-langkah penetapan yang benar. Kondisi tersebut masih jauh yang diharapkan. Tujuan dari penelitian tindakan sekolah ini untuk meningkatkan kemampuan guru SD Negeri Tegalwangi 01 dalam menetapkan Kriteria Ketuntasan Minimal tahun pelajaran 2014/2015. Penelitian tindakan sekolah ini dilakukan dalam 2 siklus dengan 4 kegiatan untuk setiap siklusnya yaitu Perencanaan, Pelaksanaan, Observasi, dan Refleksi. Metode pengumpulan data menggunakan metode observasi, penugasan, dan dokumentasi. Hasil penelitian tindakan sekolah ini menunjukkan bahwa Rapat Kerja KKG Sekolah dapat meningkatkan kemampuan guru SD Negeri Tegalwangi 01 dalam menetapkan Kriteria Ketuntasan Minimal mata pelajaran matematika tahun pelajaran 2014/2015. Hal ini dibuktikan dengan adanya peningkatan kemampuan guru dalam menentukan Kriteria Ketuntasan Minimal mata pelajaran matematika yakni pada pra siklus $25 \%$, pada siklus 1 naik menjadi $75 \%$ dan pada siklus 2 naik lagi menjadi $91 \%$.
\end{abstract}

Kata Kunci : Kriteria Ketuntasan Minimal, Mutu Pendidikan dan Profesi Guru, Rapat Kerja KKG Sekolah

\section{PENDAHULUAN}

Penetapan Kriteria Ketuntasan Minimal ( KKM ) merupakan tahapan awal pelaksanaan penilaian hasil belajarsebagai bagian dari langkah pengembangan Kurikulum Tingkat Satuan Pendidikan. Kurikulum berbasis kompetensi yangmenggunakan acuan kriteria dalam penilaian, mengharuskan pendidik dan satuan pendidikan menetapkan KKM dengananalisis dan memperhatikan mekanisme, yaitu prinsip dan langkahlangkah penetapan. Kenyataan dilapangan guru berdasar pada hasil wawancara dengan 4 guru SDN Tegalwangi 01 dalam menetapkan KKM tidak berdasarkan analisis dan tidak memperhatikan prinsip serta langkah-langkah penetapan. Mereka hanya menyalin KKM milik orang lain karena ketidaktahuan bagaimana menetapkan KKM.
Adapun tujuan penelitian ini adalah melatih kemampuan guru untuk dapat menentukan kriteria ketuntasan minimal mata pelajaran matematika yang sesuai dengan karakteristik kelas. Penelitian ini mengupayakan pengadaan rapat kerja KKG sekolah untuk berbagi pengalaman kepada guru mengenai penentuan KKM sehingga diharapkan hasil pembelajaran menjadi lebih baik.

\section{KAJIAN TEORI}

Kriteria Ketuntasan Minimal (KKM)

Perangkat Penilaian Kurikulum di

Sekolah Dasar dari Departemen

Pendidikan Nasional, dijelaskan:

Pengertian, Fungsi, dan Mekanisme 
Penetapan KKM yang isinya sebagai berikut :

\section{a. Pengertian Kriteria Ketuntasan Minimal ( KKM )}

Salah satu prinsip penilaian pada kurikulum berbasis kompetensi adalahmenggunakan acuan kriteria, yakni menggunakan kriteria tertentu dalammenentukan kelulusan peserta didik. Kriteriapaling rendah untuk menyatakanpeserta didik mencapai ketuntasan dinamakan Kriteria Ketuntasan Minimal ( KKM ).

KKM harus ditetapkansebelum awal tahun ajaran dimulai. Acuan Kriteriatidak diubah secara serta merta karena hasil empirik penilaian. Kriteria Ketuntasan Minimal ditetapkan oleh satuan pendidikan berdasarkan hasil musyawarah guru mata pelajaran di satuan pendidikan atau beberapa satuan pendidikan yang memiliki barakteristik yang hampir sama. Pertimbanganpendidik atauforum KKG secara akademis menjadi pertimbangan utamapenetapan KKM.

b. Fungsi Kriteria Ketuntasan Minimal ( KKM )

1). Sebagai acuan bagi pendidik dalam menilai kompetensi peserta didik sesuai kompetensi dasar mata pelajaran yang diikuti..

2). Sebagai acuan bagi peserta didik dalam menyiapkandiri mengikuti penilaianmata pelajaran.

3) Dapat digunakan sebagai bagian dari komponen dalam melakukanevaluasi program pembelajaran yang dilaksanakan di sekolah.

c. MekanismePenetapan KKM.

1) Prinsip Penetapan KKM Penetapan Kriteria Ketuntasan Minimal perlu mempertimbangkan beberapa ketentuan sebagai berikut :

(1) Penetapan KKM merupakan kegiatan pengambilankeputusan yang dapatdilakukan melalui metode kualitatif dan atau kuantitatif.

(2) Penetapan nilai kriteria ketuntasan minimal dilakukan melalui analisis ketuntasan belajar minimal pada setiap indikator dengan memperhatikankompleksitas, daya dukung, dan intakepeserta didik untuk mencapaiketuntasan

kompeteni dasardan standar kompetensi.

(3) Kriteria ketuntasan minimal setiap Kompetensi Dasar ( KD ) merupakan rata-rata dari indikator yang terdapat dalam Kompetensi Dasar tersebut.

(4) Kriteria ketuntasan minimal setiap Standar Kompetensi ( SK ) merupakan rata-rata KKM Kompetensi Dasar ( KD ) yang terdapat dalam SK tersebut;

(5) Kriteria Ketuntasan Minimal mata pelajaran merupakan rata-rata dari semua KKM-SK yang terdapat dalam satu semester atau satu tahunpembelajaran, dan dicantumkandalam Laporan Hasil Belajar ( LHB /Rapor ) peserta didik.

(6) Indikator merupakan acuan / rujukan bagi pendidik untuk membuat soal-soalulangan, baik Ulangan Harian ( UH ), Ulangan Tengah Semester ( ULS ) maupun Ulangan Akhir Semester (UAS ).

(7) Pada setiap indikator atau kompetensi dasar dimungkinkan adanya perbedaan nilai ketuntasan minimal.

2)Langkah-langkah Penetapan KKM

Penetapan KKM dilakukan oleh guru atau kelompok guru mata pelajaran. Langkah penetepan KKM adalah sebagai berikut :

(1) Guru atau kelompok guru menetapkan KKM mata Pelajaran dengan mempertimbangkan tiga aspek kriteria, yaitu kompleksitas, daya dukung, dan intakepeserta didik. Hasil penetapan KKM indikator berlanjut pada KD, SK hingga KKM mata pelajaran :

(2) Hasil penetapan KKM oleh guruatau kelompok guru mata pelajaran disahkan olehKepala Sekolah untuk dijadikan patokan guru dalammelakukanpenilaian;

(3) KKMyang ditetapkan disosialisasikan kepada pihakpihak yang berkepentingan, yaitu peserta didik, orang tua, dan dinas pendidikan; 
(4) KKM dicantumkan dalam LHB pada saat hasil penilaian dilaporkankepada orang tua / wali peserta didik.

3) Penentuan Kriteria Ketuntasan Minimal ( KKM )

KKM pada setiap indikator pada KD, SK dari mata pelajaran ditetapkan melalui analisis Kompleksitas, Daya Dukung, dan Intake.

(1) Kompleksitas ( S )

S1 yaitu tergolong ranah kognitif tinggi,S2 yaitu konsep abstrak bagi siswa, sedangkan S3yaitukurangnya contoh yang ditemukan siswa, dan S4 yaitu mengandung banyak istilah asing,S5yaitukurang didukung sarana,S6 yaitubahan sajian sulit dipahami

(2).Daya dukung ( D )

D1:Sarana Prasarana,

D2:Ketersediaan tenaga,

D3:Kepdulian Stake Holders,

D4:Biaya Operasional Pendidikan

D5:Manajemen Sekolah,

(3) Intake

Rata-rata nilai asal siswa untuk intake dibagi menjadi tiga tingkat, yaitu :

Tinggi, jika rata-rata $80-100$, maka poin 3 , sedang, jika rata-rata $60-79$, maka poin 2 , rendah, jika rata-rata 59 kebawah, maka poin 1

KKM indikator pada KD, SK dalam mata pelajaran adalah jumlah poin yang didapat dibagi sembilan kali seratus.

$$
K K M=\frac{\text { jlmh poin }}{9} \times 100
$$

\section{Mutu Pendidikan dan Profesi Guru}

Profesi guru yang sebenarnyasangat berkaitan erat dengan peningkatan mutu pendidikan. Hal ini dapat dijelaskan karena banyak faktor yang dapatmempengaruhimutu pendidikan seperti guru, sarana prasarana, kurikulum, dan proses belajar mengajarserta sistem penilaian. Meskipun demikian, faktor guru tidak dapat disamakan dengan faktorfaktor lainnya.

Berdasarkan hasil studibalitbang padatahun 1992, ditemukan bahwa guru yangbermutu memberikan pengaruhyang paling tinggi terhadap mutu pendidikan. Dalam studi ini, guru yangbermutu diukur dengan empat faktor utama, yaitu kemampuan profesional , upaya profesional, kesesuaian waktu yang dicurahkanuntuk kegiatan profesional, dan kesesuaian antarakeahlian dengan pekerjaannya.

\section{RapatKerjaKKG}

KKG adalah wadah pertemuan profesional para guru yang bersifat aktif, kompak dan akrab dalam membahas berbagai masalah profesional keguruan dengan prinsip dari guru, oleh guru, dan untuk guru dalam rangka pelaksanaan tugasnya. (Anonim, 1994:3).

Dalam kegiatan menyusun ketetapan KKM juga akan diadakan rapat kerja KKG, yang dihadiri oleh guru kelas di bawah binaan kepalas ekolah, dan pengawas satuan pendidikan, dilaksanakan pada awal semester karena menyusun ketetapan KKM mata pelajaran matematika sampai saat ini masih dipandang sebagai pekerjaan yang cukup sulit maka perlu dikerjakan secara berkelompok melalui rapat kerja KKG Guru Kelas.

\section{METODE PENELITIAN}

Subyek dalam penelitian ini adalah guru SDN Tegalwangi 01 yang tergabung dalam KKG sekolah yang berjumlah 12 orang. Waktu yang digunakan dalam penelitian ini adalah selama 3 bulan dari Juli sampai September2014.

Penelitian yang digunakan adalah penelitian eksperimen yangbersifat kuantitatif. Dalam hal ini, peneliti melakukan beberapa tahapan dengan mengumpulkan data-data yang diperlukan, baik secara kualitatifataupun kuantitatif.

Rencana penelitian tindakan ini ada 3 jeniskegiatan yang akandilaksanakan antara lain :

1. Jenis kegiatan adalah tindakan nyata dalam menyusun penetapan KKM mata pelajaran matematika semester ganjil 
melalui rapat kerja KKG sekolah di SDN Tegalwangi 01.

2. Bentuk kegiatanya itu dilaksanakan rapat kerja penetapan KKM mata pelajaran matematika semester ganjil bagi guru seperti yang disebut di atas di SDN Tegalwangi01.

\section{PelaksanaanTindakan}

\section{SiklusI}

Dalam siklus 1 terdiri dari perencanaan, pelaksanaan, observasi dan refleksi yang akan diuraikan sebagai berikut :

1) Perencanaan menempuh beberápa langkah-langkah yaitu :

a. Semua guru kelas dan mapel yang berjumlah 12 orang dikumpulkan di dalam satu ruangan

3) Observasi

Dilakukan sesuai dengan tahapan-tahapan pelaksanaan seperti dari membawa bahan, mengkaji KKM mata pelajaran matematika dan penentuan KKM mata pelajaran matematika.

Selanjutnya disiapkan pedoman observasi persiapan, keaktifan guru dan hasil kerja guru yang dapat dilihat melalui tabel 1 dan tabel 2 di bawah ini.

Tabel 1 Pedoman Observasi Siklus 1 dan 2 (Diisi DenganMemberikan Tanda $\sqrt{ }$ )

\begin{tabular}{|l|l|l|l|l|l|l|l|}
\hline No & \multirow{2}{*}{ Nama } & \multicolumn{5}{|c|}{ Aspek } & Hasil \\
\cline { 3 - 7 } & Guru & $\begin{array}{l}\text { Perhatian } \\
\text { kepada } \\
\text { penyaji }\end{array}$ & $\begin{array}{l}\text { Mengemuka } \\
\text { kan } \\
\text { pendapat }\end{array}$ & $\begin{array}{l}\text { Presentasi } \\
\text { internal }\end{array}$ & $\begin{array}{l}\text { Presentasi } \\
\text { eksternal }\end{array}$ & $\begin{array}{l}\text { Mengajukan } \\
\text { pertanyaan }\end{array}$ & \\
\hline 1 & & & & & & & \\
\hline 2 & & & & & & & \\
\hline 3
\end{tabular}

Catatan: Guru dianggap aktif jika terpenuhi minimal 3 aspek kegiatan

Observasi Kelas dianggap berhasil jika 75\% guru aktif

Tabel 2Lembar Penilaian Kerja guru dalam menetapkan KKM siklus 1 dan 2

\begin{tabular}{|c|c|c|c|c|c|c|}
\hline \multirow{2}{*}{ No } & \multirow{2}{*}{\begin{tabular}{c} 
Guru Kelas / \\
\cline { 3 - 5 }
\end{tabular}} & $\begin{array}{c}\text { Kesesuaian } \\
\text { langkah- } \\
\text { langkah dalam } \\
\text { Mentapan } \\
\text { KKM }\end{array}$ & $\begin{array}{c}\text { Aspek } \\
\text { perilaku } \\
(\mathrm{C} 1-\mathrm{C} 6)\end{array}$ & Hasil Akhir & \multirow{2}{*}{ Nilai } & Kategori \\
\cline { 3 - 6 } & $1-5$ & $1-5$ & $1-5$ & & \\
\hline 1 & & & & & & \\
\hline
\end{tabular}




\begin{tabular}{|c|c|l|l|l|l|l|}
\hline 2 & & & & & & \\
\hline 3 & & & & & & \\
\hline Dst & & & & & & \\
\hline & Jumlah & & & & & \\
\hline & Rata - rata & & & & & \\
\hline
\end{tabular}

a). Pedoman dalam memberi skor :

Diberi skor 5 jika unsur yang dinilai sangat sesuai dengan kriteria,diberi skor 4 jika unsur yang dinilai sesuai dengan kriteria, diberi skor 3 jika unsur yang dinilai cukup sesuai dengan kriteria, diberi skor 2 jika unsur yang dinilai kurang sesuai dengan kriteria, diberi skor 1 jika unsur yang dinilai tidak sesuai dengan kriteria

b). Total skor masksimal $=15$

$$
\text { Nilai }=\frac{\text { totalskorperolehan }}{\text { totalskor }} \times 100
$$

c). Kategori nilai :

1. $86-100=$ sangat baik (A); $66-85=$ baik( $(\mathrm{B}) ; 55-65=\operatorname{cukup}(\mathrm{C}) ; 44-55=$ kurang( D ); $25-45=$ sangat kurang ( E )

\section{4) Refleksi}

Dalam refleksi akan menempuh beberapa kegiatan sebagai berikut : Apabila 85\% guru dapat menetapkan KKM mata pelajaran matematika sesuai dengan ketentuan dikategorikan berhasil, bila kurang dari $85 \%$ guru belum dapat menetapkan KKM mata pelajaran matematika sesuai ketentuan dikatagorikan gagal sehingga wajib mengikuti siklus selanjutnya

\section{SIKLUS II}

Dalam siklus II terdiri dari perencanaan, pelaksanaan, observasi dan refleksi yang akan diuraikan sebagai berikut :

1) perencanaan menempuh beberapa langkah-langkah yaitu :

a. semua guruyang belum memenuhi parameter tentang penetapan KKM mata pelajaran matematikadikumpulkan pada satu ruangan

b. Guru membawa bahan penyusunan KKM mata pelajaran matematikaseperti, silabus, kalkulator atau laptop.

c. Guru mendengarkainformasi tentang teknik penetapan KKM mata pelajaran matematika

d. Guru membentuk kelompok sesuai dengan jenis bidang mata pelajaran

e. Guru mulai menyusun penetapan KKM mata pelajaran matematika

f. Penelitian melakukan cek silang langsung ke masingmasing kelompok guru mata pelajaran

2) Pelaksanaan

Pelaksanaan dilakukan berdasarkan rencana tindakan dan perencanaan selanjutnya ditentukan tempat penelitian di SDN Tegalwangi 01, WaktupelaksanaanPukul 09.00-13.00 WIB; tanggal kegiatan13 Agustus 2014

3) Observasi

Dilakukan sesuai dengan tahapan-tahapan pelaksanaan seperti dari membawa bahan, mengkaji KKM mata pelajaran matematika dan penentuan KKM mata pelajaran matematika Selanjutnya disiapkan pedoman observasi untuk menilai:

1. Kelengkapanbahan - bahan untuk menetapkan KKM 
mata pelajaran matematika seperti Silabus, Kalkulator atau Laptop.

2. Keaktifan guru - guru untuk mengikuti Rapat Kerja KKG sekolah.

3. Hasil akhir kerja .

4) Refleksi

Dalam refleksi akan menempuh beberapa kegiatan sebagai berikut : Bila pada siklus II, $85 \%$ guru dapat menetapkan KKM mata pelajaran matematika sesuai dengan ketentuan dikatagorikan berhasil, tidak dianggap gagal dan dirancang mengikuti siklus selanjutnya.

\section{HASIL PENELITIAN DAN PEMBAHASAN}

Dari 12 guru kelas dan guru mata pelajaran yang akan diberi tindakan, berdasar hasil wawancara semua tidak mampu menetapkan KKM mata pelajaran matematika baik prinsip penetapan KKM maupun langkah-langkah dalam menetapkan KKM mata pelajaran matematika.

Siklus pertama dilaksanakan pada hari Sabtu tanggal 9 Juli 2014 di Kantor guru SDN Tegalwangi 01 dari pukul 09.00 sampai dengan pukul 13.00 WIB. Dalam tahap ini 11 guru yang belum memenuhi parameter tentang penetapan KKM mata pelajaran matematika diundang untuk mengikuti rapat kerja KKG sekolah dan diminta membawa bahan penyusunan KKM mata pelajaran matematikaseperti, silabus, kalkulator atau disediakan laptop.

1) Implementasi tindakan

Dalam pelaksanaan tindakan, guru dikumpulkan dalam suatu ruangan untuk mengadakan rapat kerja KKG sekolah. Rapat Kerja KKG sekolah diawali dengan mendengarkaninformasi tentang teknik penetapan KKM mata pelajaran matematika dilanjutkan dengan guru membentuk kelompok sesuai dengan jenis bidang mata pelajaran kemudian guru mulai menyusun penetapan KKM mata pelajaran matematika.

2) Pengamatan

Pada tahap ini, kepala sekolah sebagai peneliti melakukan pemantauan selama kegiatan rapat kerja KKG sekolah berlangsung dengan lembar observasi yang telah tersedia. Aktivitas yang diamati dari tahap persiapan, pelaksanaan kegiatan dan hasil kerja guru.

Tabel 3 Hasil Observasi Siklus 1 (Diisi Dengan Memberikan Tanda $\sqrt{ }$ )

\begin{tabular}{|c|c|c|c|c|c|c|c|}
\hline \multirow[t]{2}{*}{$\mathrm{Nc}$} & \multirow{2}{*}{$\begin{array}{l}\text { Nama } \\
\text { Guru }\end{array}$} & \multicolumn{3}{|r|}{ Aspek } & \multicolumn{2}{|l|}{ Kegiatan } & \multirow[t]{2}{*}{ Hasil } \\
\hline & & $\begin{array}{l}\text { Perhatian } \\
\text { kepada penyaji }\end{array}$ & $\begin{array}{l}\text { Mengemuk } \\
\text { akan } \\
\text { pendapat }\end{array}$ & $\begin{array}{l}\text { Presentasi } \\
\text { internal }\end{array}$ & $\begin{array}{l}\text { Presentasi } \\
\text { eksternal }\end{array}$ & $\begin{array}{l}\text { Mengaju } \\
\text { kan } \\
\text { pertanya } \\
\text { an }\end{array}$ & \\
\hline 1 & $\bar{A}$ & $\sqrt{ }$ & $\sqrt{ }$ & $\sqrt{ }$ & & $\sqrt{ }$ & AKTIF \\
\hline 2 & $\mathrm{~B}$ & $\sqrt{ }$ & $\sqrt{ }$ & & & $\sqrt{ }$ & AKTIF \\
\hline 3 & $\mathrm{C}$ & $\sqrt{ }$ & & & $\sqrt{ }$ & $\sqrt{ }$ & $\overline{\text { AKTIF }}$ \\
\hline 4 & $\mathrm{D}$ & $\sqrt{ }$ & $\sqrt{ }$ & & & & $\begin{array}{c}\text { TDK } \\
\text { AKTIF }\end{array}$ \\
\hline 5 & $\mathrm{E}$ & $\sqrt{ }$ & & & $\sqrt{ }$ & $\sqrt{ }$ & $\begin{array}{c}\text { TDK } \\
\text { AKTIF }\end{array}$ \\
\hline 6 & $\mathrm{~F}$ & $\sqrt{ }$ & $\sqrt{ }$ & & & $\sqrt{ }$ & AKTIF \\
\hline
\end{tabular}




\begin{tabular}{|l|l|c|c|c|c|c|c|}
\hline 7 & G & $\sqrt{ }$ & & & $\sqrt{ }$ & TDK \\
\hline 8 & H & $\sqrt{ }$ & $\sqrt{ }$ & $\sqrt{ }$ & & $\sqrt{ }$ & AKTIF \\
\hline 9 & I & $\sqrt{ }$ & $\sqrt{ }$ & & & $\sqrt{ }$ & AKTIF \\
\hline 10 & J & $\sqrt{ }$ & $\sqrt{ }$ & & & $\sqrt{ }$ & AKTIF \\
\hline 11 & K & $\sqrt{ }$ & & $\sqrt{ }$ & $\sqrt{ }$ & AKTIF \\
\hline 12 & L & $\sqrt{ }$ & & $\sqrt{ }$ & $\sqrt{ }$ & AKTIF \\
\hline
\end{tabular}

Catatan: Guru dianggap aktif jika terpenuhi minimal 3 aspek kegiatan

Observasi Kelas dianggap berhasil jika 75\% guru aktif

Aktif $\quad: 9 / 12 \times 100 \%=75 \%$

Pasif $\quad: 3 / 12 \times 100 \%=25 \%$.

Berdasarkan data tabel tersebut menunjukkan keaktifan guru sebesar $75 \%$ yang mengandung arti bahwa rapat kerja KKG sekolah diikuti secara aktif oleh semua guru.

Sedangkan dari pengamatan hasil kerja didapatkan 5guru belum dapat menetapkan KKM seperti tertera pada pengamatanHasil kerja guru melalui tabel di bawah ini:

Tabel 4 Penilaian Kerja guru dalam menetapkan KKM siklus 1

\begin{tabular}{|c|c|c|c|c|c|c|}
\hline \multirow{2}{*}{ No } & \multirow{2}{*}{$\begin{array}{c}\text { Guru } \\
\text { Mata } \\
\text { pelajar } \\
\text { an }\end{array}$} & $\begin{array}{c}\text { Kesesuaian } \\
\text { langkah- } \\
\text { langkah dalam } \\
\text { penetapan } \\
\text { KKM }\end{array}$ & $\begin{array}{c}\text { Aspek } \\
\text { perilaku } \\
(\mathrm{C} 1-\mathrm{C} 6)\end{array}$ & Hasil Akhir & \multirow{2}{*}{ Nilai } & Kategori \\
\cline { 3 - 6 } & $1-5$ & $1-5$ & $1-5$ & & \\
\hline 1 & & 3 & 4 & 1 & 53 & D \\
\hline 2 & & 3 & 4 & 3 & 67 & B \\
\hline 3 & & 4 & 3 & 3 & 67 & B \\
\hline 4 & & 3 & 3 & 1 & 47 & D \\
\hline 5 & & 4 & 3 & 3 & 67 & B \\
\hline 6 & & 3 & 3 & 1 & 47 & D \\
\hline 7 & & 2 & 4 & 3 & 60 & C \\
\hline
\end{tabular}




\begin{tabular}{|c|c|c|c|c|c|c|}
\hline 8 & & 3 & 5 & 3 & 73 & $\mathrm{~B}$ \\
\hline 9 & & 2 & 4 & 1 & 47 & $\mathrm{D}$ \\
\hline 10 & 4 & 4 & 4 & 80 & $\mathrm{~B}$ \\
\hline 11 & 3 & 3 & 2 & 53 & $\mathrm{D}$ \\
\hline 12 & & 4 & 5 & 5 & 93 & $\mathrm{~A}$ \\
\hline & $\begin{array}{c}\text { Jumlah } \\
\text { Rata - } \\
\text { rata }\end{array}$ & 38 & 45 & 30 & 751 & \\
\hline
\end{tabular}

3) Refleksi

Ada tiga hal yang menjadi fokus refleksi pada siklus ini, yakni 1) Kelengkapanbahan - bahan untuk menetapkan KKM mata pelajaran matematika seperti Silabus, Kalkulator atau Laptop, 2) Keaktifan guru dalam mengikuti kegiatan dan 3) Hasil kerja subjek penelitian berupa KKM mata pelajaran matematika yang telah ditetapkan dengan langkah-langkah yang sesuai.

Berdasar hasil pengamatan semua guru membawa silabus, 6 orang guru membawa kalkulator dan 5 guru membawa laptop. Hal ini menunjukkan keseriusan guru dalam mengikuti kegiatan. Demikian pula dari hasil pengamatan keaktifan guru, semua guru aktif mengikuti kegiatan. Sedangkan dari pengamatan hasil kerja didapatkan 5guru belum dapat menetapkan KKM mata pelajaran matematika.

1. Siklus 2

1) Perencaanaan

Siklus kedua dilaksanakan pada hari Sabtu tanggal 13 Agustus 2014 di Kantor guru SDN Tegalwangi 01 dari pukul 09.00 sampai dengan pukul 13.00 WIB. Dalam tahap ini 12 guru diundang untuk mengikuti rapat kerja KKG sekolah dan diminta membawa bahan penyusunan KKM seperti, silabus, kalkulator atau disediakan laptop.

2) Implementasi tindakan

Dalam pelaksanaan tindakan, guru dikumpulkan dalam suatu ruangan untuk mengadakan rapat kerja KKG sekolah. Rapat Kerja KKG sekolah diawali dengan mendengarkaninformasi tentang teknik penetapan KKM mata pelajaran matematikadilanjutkan dengan membentuk kelompok kemudian guru mulai menyusun penetapan KKM mata pelajaran matematika didampingi operator sekolah yang mampu mengoperasikan komputer.

\section{Pengamatan}

Berdasar hasil pengamatan semua guru membawa silabus, 6 orang guru membawa kalkulator dan 7 guru membawa laptop. Hal ini menunjukkan keseriusan guru dalam mengikuti kegiatan. Demikian pula dari hasil pengamatan keaktifan guru, semua guru aktif mengikuti kegiatan dapat di lihat dari table di bawah ini

Tabel 5 Hasil Observasi Siklus 2 (Diisi Dengan Memberikan Tanda $\sqrt{ }$ )

\begin{tabular}{|l|l|l|l|l|l|l|l|}
\hline No & Nama & \multicolumn{4}{|c|}{ Aspek } & Hasil \\
\cline { 3 - 6 } & \multirow{2}{*}{ Guru } & $\begin{array}{l}\text { Perhatian } \\
\text { kepada } \\
\text { penyaji }\end{array}$ & $\begin{array}{l}\text { Mengemuka } \\
\text { kan } \\
\text { pendapat }\end{array}$ & $\begin{array}{l}\text { Presenta } \\
\text { si } \\
\text { internal }\end{array}$ & $\begin{array}{l}\text { Presentasi } \\
\text { eksternal }\end{array}$ & $\begin{array}{l}\text { Mengajukan } \\
\text { pertanyaan }\end{array}$ & \\
\hline
\end{tabular}




\begin{tabular}{|c|c|c|c|c|c|c|c|}
\hline 1 & $\mathrm{~A}$ & $\sqrt{ }$ & $\sqrt{ }$ & $\sqrt{ }$ & & $\sqrt{ }$ & AKTIF \\
\hline 2 & B & $\sqrt{ }$ & $\sqrt{ }$ & & & $\sqrt{ }$ & AKTIF \\
\hline 3 & $\mathrm{C}$ & $\sqrt{ }$ & & & $\sqrt{ }$ & $\sqrt{ }$ & AKTIF \\
\hline 4 & $\mathrm{D}$ & $\sqrt{ }$ & $\sqrt{ }$ & $\sqrt{ }$ & $\sqrt{ }$ & & AKTIF \\
\hline 5 & $\mathrm{E}$ & $\sqrt{ }$ & & & $\sqrt{ }$ & $\sqrt{ }$ & $\begin{array}{c}\text { TDK } \\
\text { AKTIF }\end{array}$ \\
\hline 6 & $\bar{F}$ & $\sqrt{ }$ & $\sqrt{ }$ & & & $\sqrt{ }$ & AKTIF \\
\hline 7 & $\mathrm{G}$ & $\sqrt{ }$ & & $\sqrt{ }$ & $\sqrt{ }$ & $\sqrt{ }$ & AKTIF \\
\hline 8 & $\mathrm{H}$ & $\sqrt{ }$ & $\sqrt{ }$ & $\sqrt{ }$ & & $\sqrt{ }$ & AKTIF \\
\hline 9 & I & $\sqrt{ }$ & $\sqrt{ }$ & & & $\sqrt{ }$ & AKTIF \\
\hline 10 & $\mathrm{~J}$ & $\sqrt{ }$ & $\sqrt{ }$ & & & $\sqrt{ }$ & AKTIF \\
\hline 11 & $\mathrm{~K}$ & $\sqrt{ }$ & & $\sqrt{ }$ & $\sqrt{ }$ & & AKTIF \\
\hline 12 & $\mathrm{~L}$ & $\sqrt{ }$ & & $\sqrt{ }$ & $\sqrt{ }$ & $\sqrt{ }$ & AKTIF \\
\hline
\end{tabular}

Catatan: Guru dianggap aktif jika terpenuhi minimal 3 aspek kegiatan

Observasi Kelas dianggap berhasil jika 75\% guru aktif

Aktif $\quad: 11 / 12 \times 100 \%=91,7 \%$

Pasif : $1 / 12 \times 100 \% \quad=8,3 \%$

Berdasarkan data tabel tersebut menunjukkan keaktifan dari guru meningkat dari $75 \%$ menjadi $91,7 \%$ yang mengandung arti bahwa rapat kerja KKG sekolah diikuti secara lebih aktif oleh semua guru.

Sedangkan dari pengamatan hasil kerja didapatkan semua guru mampu menetapkan KKM mata pelajaran matematika seperti tertera pada pengamatanhasil kerja guru melalui tabel di bawah ini.

Tabel 6Penilaian Kerja guru dalam menetapkan KKMMapel Matematika siklus 2

\begin{tabular}{|c|c|c|c|c|c|c|}
\hline \multirow{3}{*}{ No } & \multirow{3}{*}{$\begin{array}{l}\text { Guru Kelas / } \\
\text { Mata pelajaran }\end{array}$} & \multicolumn{3}{|c|}{ Aspek dan skor } & \multirow[b]{2}{*}{ Nilai } & \multirow[b]{2}{*}{ Kategori } \\
\hline & & $\begin{array}{c}\text { Kesesuaian } \\
\text { langkah- } \\
\text { langkah dalam } \\
\text { penetapan } \\
\text { KKM }\end{array}$ & $\begin{array}{c}\text { Aspek } \\
\text { perilaku } \\
(\mathrm{C} 1-\mathrm{C} 6)\end{array}$ & Hasil Akhir & & \\
\hline & & $1-5$ & $1-5$ & $1-5$ & & \\
\hline 1 & Taprikhatul & 3 & 4 & 2 & 60 & $\mathrm{C}$ \\
\hline 2 & EmutSetiowati & 3 & 4 & 4 & 73 & B \\
\hline 3 & Mahiroh & 4 & 4 & 3 & 73 & B \\
\hline 4 & A. Marzuki & 4 & 3 & 3 & 67 & B \\
\hline 5 & Nur Chasanah & 4 & 3 & 3 & 67 & $\mathrm{~B}$ \\
\hline
\end{tabular}




\begin{tabular}{|c|l|c|c|c|c|c|}
\hline 6 & Suprapti & 3 & 3 & 4 & 67 & B \\
\hline 7 & Sujarwo & 3 & 4 & 3 & 67 & B \\
\hline 8 & Muarip & 3 & 5 & 3 & 73 & B \\
\hline 9 & Ahmad Rohan & 3 & 4 & 3 & 67 & B \\
\hline 10 & Panca Rahayu & 4 & 4 & 4 & 80 & B \\
\hline 11 & DimasFathir & 3 & 3 & 3 & 60 & C \\
\hline 12 & Nurkhakim & 4 & 4 & 5 & 87 & A \\
\hline & Jumlah & 41 & 45 & 40 & 840 & \\
\hline & Rata - rata & 3,4 & 3,75 & 3,3 & 70 & B \\
\hline
\end{tabular}

\section{Refleksi}

Ada 1 hal yang menjadi fokus refleksi pada siklus ini, yakni Hasil kerja subjek penelitian berupa KKM mata pelajaran matematika yang telah ditetapkan dengan langkah-langkah yang sesuai.

Berdasar hasil pengamatan semua guru membawa silabus, 6 orang guru membawa kalkulator dan 5 guru membawa laptop. Hal ini menunjukkan keseriusan guru dalam mengikuti kegiatan. Demikian pula dari hasil pengamatan keaktifan guru sebesar $75 \%$ menunjukkan guru aktif mengikuti kegiatan.

Hasil wawancara dengan mereka yang belum menetapkan KKM mata pelajaran matematikabahwa belum menentukan KKM bukan karena tidak tahu langkah-langkahnya tetapi karena mereka belum bisa mengoperasikan komputer sehingga mereka tertinggal dengan rekan-rekannya yang sudah mampu mengoperasikan komputer.

Dari permasalahan yang muncul berdasarkan hasil refleksiyang selanjutnya menjadi bahan perbaikan untuk siklus berikutnya adalah: Sekolah menyediakan tenaga TU yang mampu mengoperasikan komputer untuk membantu guru yang belum bisa mengoperasikan komputer dalam rapat kerja KKG sekolah.

1) Pembahasan Data Siklus 2

Pada siklus ini telah dilaksanakan berbagai usulan perbaikan yang disarankan pada siklus sebelumnya. Hasil pengamatan menunjukkan adanya peningkatan komptensi guru dalam menetapkan KKM. mata pelajaran matematika Hal ini bisa dibuktikan dengan semua guru mampu menyelesaikan penetapan KKM mata pelajaran matematikadengan langkah-langkah penetapan yang sesuai.

Hasil pembahasan dan analisis data pada siklus 2 adalah sebagai berikut:

1) Keaktifan guru mengikuti kegiatan raker kerja KKG sekolah meningkat dari $75 \%$ menjadi $91,7 \%$

2) Adanya peningkatan keterampilan guru dalam pembuatan KKM mata pelajaran matematikadari sejumlah $67 \%$ guru menjadi $100 \%$.

Hal ini menunjukkan bahwa rapat kerja KKGsekolah benar-benar efektif untuk meningkatkan kemampuan professional guru khususnya dalam pembuatan KKM mata pelajaran matematikahal ini sesuai dengan KKG. Hasil penelitian ini sekalipun sangat sederhana menunjukkan bahwa kemampuan guru dalam menguasai TIK sangat penting untuk membantu kelancaran tugas-tugas profesinya.

\section{PENUTUP}

\section{Simpulan}

Berdasarkan hasil pelaksanaan penelitian tindakan sekolah (PTS) tersebut di atasdapat disimpulkan bahwa rapat kerja KKG sekolah dapat meningkatkan kemampuan guru dalam menetapkanKriteria Ketuntasan Minimal 
(KKM) mata pelajaran matematika di SDN Tegalwangi 01 tahun pelajaran 2014-2015.

Hasil analisa dan refleksi hal ini disebabkan dalam rapat kerja KKG adalah wadah pertemuan profesional para guru yang bersifat aktif, kompak dan akrab dalam membahas berbagai masalah profesional keguruan dengan prinsip dari guru, olehguru, dan untuk guru dalam rangka pelaksanaan tugasnya.

\section{Saran}

Adapun saran yang dapat penulis sampaikan kepada Kepala Sekolah disarankan dalam menetapkan KKM mata pelajaran matematika hendaknya menyelenggarakan rapat kerja KKG sekolah agar kerja sama guru dan saling tukar informasi dapat terbina dengan baik dalam mewujudkan peningkatan mutu sekolah.

Kepada semua guru dalam melaksanakan tugas untuk menetapkan KKM mata pelajaran matematikasangat perlu mengadakan kerja sama dan bertukar pikiran dengan guru sejenis atupun guru mata pelajaran lain.

\section{DAFTAR PUSTAKA}

Basuki, Wibawa,2003. Penelitian Tindakan Kelas, Jakarta :Departemen Pendidikan Nasional Direktorat Pendidikan Dasar dan Menengah Direktorat Tenaga Kependidikan.

2003. Undang-Undang Republik Indonesia Nomor 20 Tahun 2003 Tentang Sistem Pendidikan Nasional, Biro Hukum dan Organisasi Sekretariat Jendral Departemen Pendidikan Nasional.

.2004,PeningkatanKinerjaKepalaSekol ah, Jakarta Direktorat Jenderal Pendidikan Dasar dan Menengah Direktorat Taman Kanak-Kanak dan Sekolah Dasar.

2005, Undang-Undang Republik Indonesia Tahun 2005. Jakarta. Tentang Guru dan Dosen. Cemerlang: Jakarta
2008. Pedoman Pendampingan Penelitian Tindakan Sekolah (School Action Research) Bagi Pengawas Sekolah SD dan SMP, Jakarta: Direktorat Jenderal Peningkatan Mutu Pendidikan dan Tenaga Kependidikan Direktorat Tenaga Kependidikan.

IGAK Wardhani, dkk, 2007. PenelitianTindakanKelas, Jakarta: Universitas Terbuka.

Suharsimi, Arikanto, danSuharjono, Supardi. 2006, PenelitianTindakanKelas, Jakarta: BumiAksara. 
52 EduMa Vol. 6 No. 2 Desember 2017

ISSN 2086 - 3918 